Type of the Paper (Article, Review, Communication, etc.)

\title{
Liquid-liquid extraction of ferric ions into the ionic liquids
}

\author{
Katerina Cubova ${ }^{1 *}$, Miroslava Semelova ${ }^{1}$, Mojmir Nemec ${ }^{1}$ and Vit Benes ${ }^{1,}$ \\ 1 Department of Nuclear Chemistry, Faculty of Nuclear Sciences and Physical Engineering, Czech Technical \\ University, 11519 Prague, Czech Republic \\ * Correspondence katerina.cubova@fffi.cvut.cz;
}

\begin{abstract}
Imidazolium ionic liquids containing acetylacetone, thenoyltrifluoroacetone, or 8-hydroxyquinoline, respectively, were used as the extracting agents for the separation of traces of iron (III) from its aqueous solutions with or without citric and oxalic acids. The results show that 8-hydroxyquinoline in imidazolium ionic liquids extract iron quantitatively from all the tested solutions including complexing ones, regardless indications of unexpected iron behavior/speciation.
\end{abstract}

Keywords: ionic liquids, liquid-liquid extraction, iron extraction, 8-hydroxyquinoline, acetylacetone, thenoyltrifluoroacetone

\section{Introduction}

At present days, ionic liquids become increasingly interesting for researchers in a wide range of fields. They play an important role for many current technologies from hydrometallurgy to food processing [1]. These substances gained attention of scientists due to their unique and tunable properties depending on the exact structure of the anion and cation [2]. Among their advantages, wide liquid range, high thermal stability, low melting points, and a near absence of vapor pressure may be listed, too [3].

Although the possibility of tuning the properties of ionic liquids can lead to their specific use, ionic liquids can also be used as a substitute for conventional organic solvents, when they may be used in nearly any area where the conventional molecular solvents are traditionally employed. Liquid-liquid extraction is being one of the most evident application for the purpose of purifying or concentrating the substances [1]and it also seems to be very promising way for the separation of metals and radionuclides in the treatment of an industrial waste.

The imidazolium ionic liquids are usually used as solvents for suitable extracting agents and they have been successfully tested in the extraction of a variety of metals [1,4]; in many cases the combination with extracting agent caused the synergistic effect. [5]. Additional advantages of this group of ionic liquids are their acceptable viscosity of the ones with short carbon chains, and relatively high (electro)chemical stability, what allows various possibilities for their regeneration [5-8].

Extraction of iron from high to trace concentration s plays important role in many of the fields mentioned above, i.e. waste streams treatment, determination of iron in minerals, separation and purification of radionuclide solutions, in water treatment, organic synthesis, and many others. [3,5]

Main aim of the research was to study the extraction of $\mathrm{Fe}$ (III) in trace concentrations into the selected ionic liquids with various extracting agents, from nitric acid aqueous solution and in the presence of complexing agents in the aqueous phase.

\section{Materials and Methods}

Chemicals

Five ionic liquids, listed below, were purchased from Iolitec, Germany (high-purity grade, $99 \%$ ) and used without additional purification.

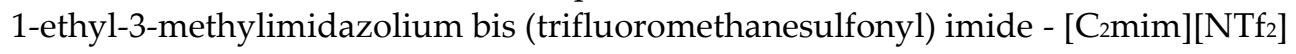


1-butyl-3-methylimidazolium bis (trifluoromethanesulfonyl) imide - [ $\left.\mathrm{C}_{4} \mathrm{mim}\right]\left[\mathrm{NTf}_{2}\right]$

1-hexyl-3-methylimidazolium bis (trifluoromethanesulfonyl) imide - [C 6 mim][NTf 2 ]

Methyltrioctylammonium bis (trifluoromethanesulfonyl) imide - [ $\left.\mathrm{N}_{1888}\right]\left[\mathrm{NTf}_{2}\right]$

Tributylmethylammonium bis (trifluoromethanesulfonyl) imide - [ $\left.\mathrm{N}_{1444}\right]\left[\mathrm{NTf}_{2}\right]$

For comparison with classic VOC representatives, benzene ( $\geq 99.7 \%$, Lachema, Brno) and chloroform (pure, Lachema Brno) were used.

As the extraction agent, acetylacetone (AcAc, purity $\geq 98 \%$, Carl Roth $\mathrm{GmbH}+\mathrm{Co}$. KG), 8-hydroxyquinoline (8HQ, SIGMA-ALDRICH CHEMIE GmbH 99\%) and thenoyltrifluoroacetone (TTA, purity $99 \%$, SIGMA-ALDRICH CHEMIE GmbH) were tested.

Nitric acid, hydrochloric acid, sodium tetraborate decahydrate and citric acid ( $\left.\mathrm{H}_{3} \mathrm{Cit}\right)$ (Lach-Ner s.r.o., Neratovice, p.a.), sodium dihydrogenphosphate, sodium hydroxide (Penta, Prague, p.a.), and sodium hydrogenphosphate, and oxalic acid $\left(\mathrm{H}_{2} \mathrm{Ox}\right)$ (Lachema Brno, p.a.) were used for preparation of aqueous phase.

The aqueous phase was spiked with stock solution of ${ }^{59} \mathrm{Fe}$ prepared from commercially available radionuclide solution of carrier-free ${ }^{59} \mathrm{FeCl}_{3}$ in $0.5 \mathrm{M} \mathrm{HCl}$, with reference activity $\mathrm{A}=37 \mathrm{MBq}(99 \%$, Perkin Elmer).

Instrumentation and methods

Organic phase was prepared by dissolving of appropriate amount of extracting agent in respective ionic liquid or benzene or chloroform.

The aqueous phase varied according to the needs of the study:

- $\mathrm{HNO}_{3}$ in concentration of 0.001-1.5 mol.L-1 or

- $0.2 \mathrm{M}$ phosphate buffer or

- $0.1 \mathrm{M}$ borate buffer or

- $\quad 0.01 \mathrm{M} \mathrm{H}_{2} \mathrm{Ox}$ or $0.005 \mathrm{M} \mathrm{H}_{3} \mathrm{Cit}$ or the mixture of $0.01 \mathrm{M} \mathrm{H}_{2} \mathrm{Ox}$ and $0.005 \mathrm{M} \mathrm{H}_{3} \mathrm{Cit}$

In all cases, the distribution ratio (D) and the percent of extraction (E) were calculated from net count rates of the analyzed nuclide in the aqueous and organic phases measured at the same conditions, Eq. (1).

$$
D=\frac{c_{\text {org }}}{c_{a q}} \approx \frac{I_{\text {org }}}{I_{a q}}, E=100 \frac{c_{\text {org }}}{c_{\text {tot }}} \approx 100 \frac{I_{\text {org }}}{I_{\text {aq }}+I_{\text {org }}}
$$

where corg, Caq are concentrations and Iorg, Iaq net specific count rates in the aqueous and organic phases, respectively, and ctot total concentration of analyte. The maximum and minimum determinable distribution ratios $\left(D_{\max }, D_{\min }\right)$ and percent of extraction (Emax, Emin) were calculated using count rate limits of detection for each experimental set [9].

The uncertainty of the distribution ratios was evaluated as a combined uncertainty of the statistics of the measurement and pipetting and it did not exceed $5 \%$ in all experiments.

Extraction experiments were performed as follows:

1. Equal volumes $(1 \mathrm{~mL})$ of organic and aqueous phases were contacted in Eppendorf microvials and shaken for 30 minutes at laboratory temperature.

2. Aqueous and organic phases were separated by centrifugation ( $5 \mathrm{~min}$ at $700 \mathrm{RCF}$ )

3. $200 \mu \mathrm{l}$ aliquots were taken from both phases and measured in a well-type 2 " NaI (Tl) scintillation detector connected to a NV 3102 single channel counter.

4. After the separation of phases, the equilibrium $\mathrm{pH}$ values of the aqueous phase were measured using digital $\mathrm{pH}$ meter PHM240 equipped with combination Red-Rod glass electrode.

\section{Results and Discussions}

Pre-experimental screening confirmed the presumption of negligible iron(III) extraction into pure imidazolium ionic liquid. Therefore, the selection of extractants based on 
their solubility in the tested ILs, and their extraction abilities was performed. Based on the results, acetylacetone (AcAc), 8-hydroxyquinoline (8HQ) and thenoyltrifluoroacetone (TTA) were selected for detailed extraction experiments including parameters strongly influencing the extraction, such as $\mathrm{pH}$ of aqueous phase, different type of ionic liquids, the composition of organic phase, concentration of extractant, and presence of organic complexing agents in aqueous phase, were studied in details.

\section{Acetylacetone}

As it is shown at Figure 1.(a), the trend of the extraction dependence on $\mathrm{pH}$ value with acetylacetone as the extracting agent $(\mathrm{pKa}=8.82)[10]$ is similar for all used solvents. The highest extraction was achieved in the $\mathrm{pH}$ range 4-9, and around $\mathrm{pH} 11$, the drop of the $\mathrm{E}$ was observed. In the $\mathrm{pH}$ range with maximal extraction, the $\mathrm{E}$ of $\mathrm{Fe}(\mathrm{III})$ extraction into acetylacetone in different solvents increased in the order of $\left[\mathrm{N}_{1444}\right]\left[\mathrm{NTf}_{2}\right]<\left[\mathrm{N}_{1888}\right]\left[\mathrm{NTf}_{2}\right]<$ $\left[\mathrm{C}_{\mathrm{x}} \mathrm{mim}\right]\left[\mathrm{NTf}_{2}\right]<$ benzene. In this range, more than $98 \%$ of iron was extracted into AcAc solution in [ $\left.\mathrm{C}_{4} \mathrm{mim}\right]\left[\mathrm{NTf}_{2}\right]$. The efficiency of extraction into ammonium based ionic liquids $\left(\left[\mathrm{N}_{1444}\right]\left[\mathrm{NTf}_{2}\right]\right.$ and $\left.\left[\mathrm{N}_{1888}\right]\left[\mathrm{NTf}_{2}\right]\right)$ is lower - the achieved maximum extraction was no more than $85 \%$. Comparing to benzene as the conventional VOC mainly used for dissolving acetylacetone where almost quantitative extraction was reached, the Fe(III) extraction into selected ionic liquids is less effective.

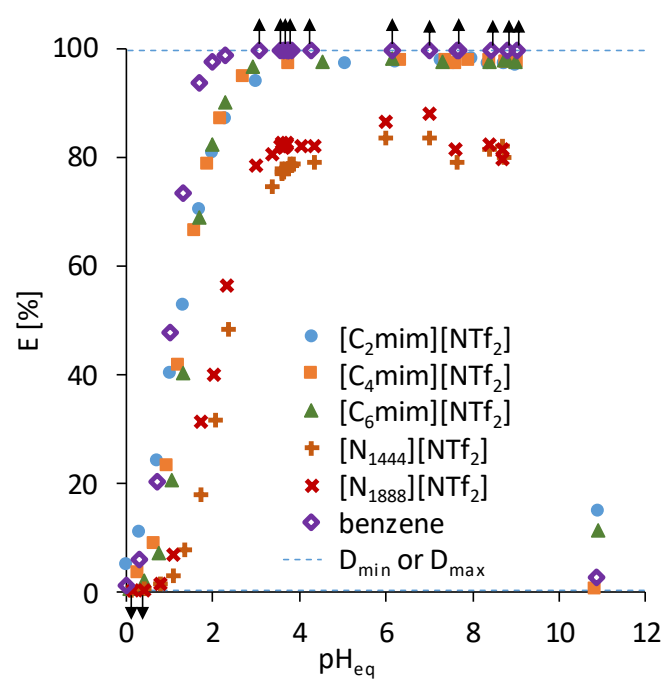

(a)

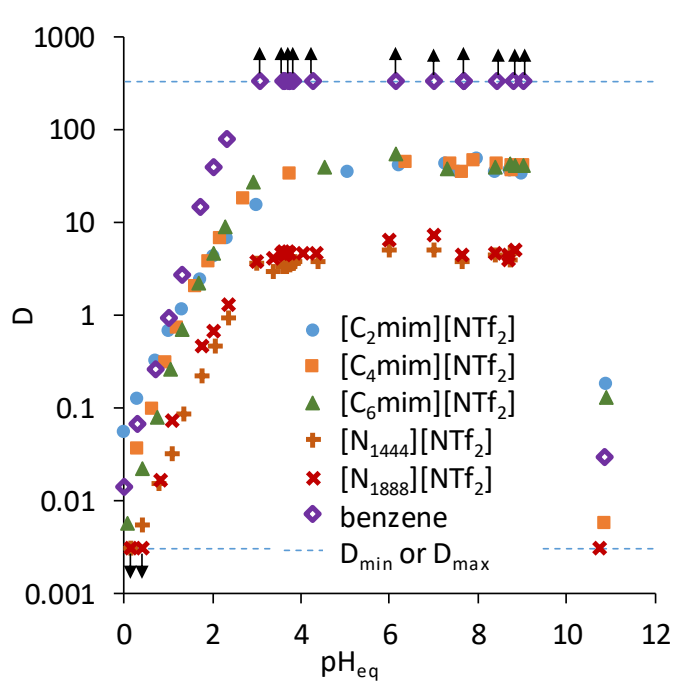

(b)

Figure 1. The dependence of (a) the percentage of extraction (E) and (b) the distribution ratio (D) on the equilibrium $\mathrm{pH}$ value for extraction of ferric ion into $0.5 \mathrm{M} A c A c$ in various ionic liquids or in benzene $\left(\mathrm{V}_{\text {org }} / \mathrm{V}_{\mathrm{aq}}=1, \mathrm{~T}=25^{\circ} \mathrm{C}, \mathrm{t}(\mathrm{contact})=\right.$ $30 \mathrm{~min}$ )

The distribution ratio (D) dependence on equilibrium $\mathrm{pH}$ (Figure 1.(b)) showed strictly linear behavior in the $\mathrm{pH}$ range $0-4$. Slopes of these linear trends and related $\mathrm{pH}_{1 / 2}$ values ( $\mathrm{pH}$ at equilibrium at which $\mathrm{D}=1$ ) were calculated (Table 1.). The highest slope value was found for the benzene environment, in the case of ILs the slope value as well as the $\mathrm{pH}_{1 / 2}$ increases with the alkyl chain length of imidazolium ionic liquids $\left(\mathrm{C}_{\mathrm{x}} \mathrm{mim}\right)$. In the case of ammonium ionic liquids, the possible trend is hidden within uncertainty interval.

In addition, the dependence of distribution ratio (D) on concentration of extracting agent in IL at constant $\mathrm{pH}$ was compared to the same dependence for benzene as a solvent (Figure 2.) and it shows that increasing AcAc concentration in the [ $\left.\mathrm{C}_{4} \mathrm{mim}\right]\left[\mathrm{NTf}_{2}\right]$ system is less effective when compared to benzene system; ionic liquid influences chelate behavior and related extraction mechanism. 
Table 1. Slopes and $\mathrm{pH}_{1 / 2}$ values calculated from the dependence of $\mathrm{D}$ on equilibrium $\mathrm{pH}$ for extraction of ferric ion into $0.5 \mathrm{M}$ AcAc in various ionic liquids or in benzene

$\left(\mathrm{V}_{\text {org }} / \mathrm{V}_{\mathrm{aq}}=1, \mathrm{~T}=25^{\circ} \mathrm{C}, \mathrm{t}(\right.$ contact $\left.)=30 \mathrm{~min}\right)$.

\begin{tabular}{|c|c|c|c|c|c|c|}
\hline & {$\left[\mathrm{C}_{2} \mathrm{~m}\right.$} & {$\left[\mathrm{C}_{4}\right.$} & $\left.\mathrm{Tf}_{2}\right]$ & {$\left[\mathrm{N}_{1444}\right]\left[\mathrm{NTf}_{2}\right]$} & {$\left[\mathrm{N}_{1888}\right]\left[\mathrm{NTf}_{2}\right]$} & ben \\
\hline op & $0.93 \pm C$ & 1.19 & 1.33 & $1.17 \pm 0.03$ & $1.20 \pm 0.17$ & $1.64 \pm 0.05$ \\
\hline $\mathrm{oH_{1/2 }}$ & $1.31 \pm 0.06$ & $1.46 \pm 0.10$ & $1.59 \pm 0.14$ & $2.33 \pm 0.08$ & $2.15 \pm 0.31$ & $1.06 \pm 0.05$ \\
\hline
\end{tabular}

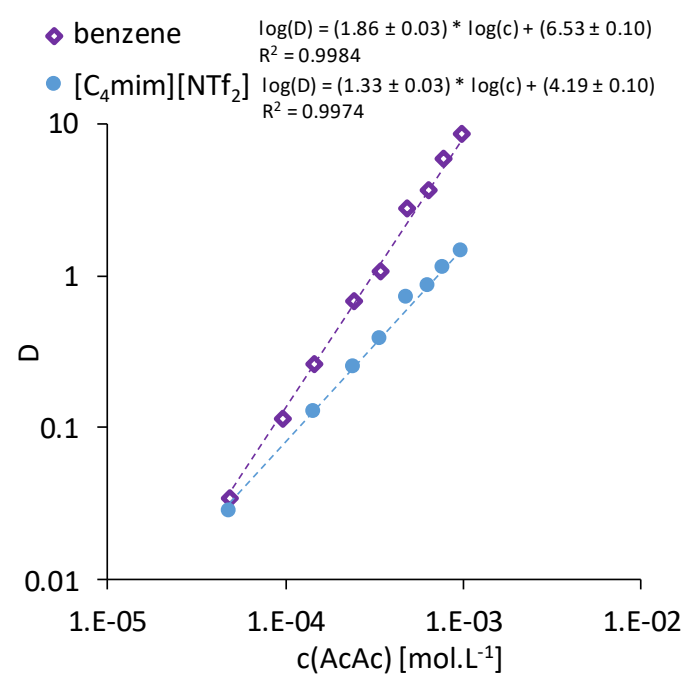

Figure 2. The dependence of the distribution ratio (D) on the concentration of AcAc at constant equilibrium $\mathrm{pH}$ value for extraction of ferric ion into $A c A c$ in $\left[\mathrm{C}_{4} \mathrm{mim}\right]\left[\mathrm{NTf}_{2}\right]$ or in benzene $\left(\mathrm{V}_{\text {org }} / \mathrm{V}_{\text {aq }}=1, \mathrm{~T}=25^{\circ} \mathrm{C}, \mathrm{t}(\mathrm{contact})=30 \mathrm{~min}\right)$

\section{Thenoyltrifluoroacetone}

For this extraction agent $\left(\mathrm{pK}_{\mathrm{a}}=6.23\right)[10]$ only benzene as conventional VOC solvent and $\left[\mathrm{C}_{4} \mathrm{mim}\right]\left[\mathrm{NTf}_{2}\right]$ representing ionic liquids were tested. As in the case of AcAc, the trend of the $\mathrm{Fe}(\mathrm{III})$ extraction dependences on equilibrium $\mathrm{pH}$ for IL and benzene as solvents are similar. The maximum extraction efficiency (98\%) was reached at $\mathrm{pH}$ close to 4 (Figure 3.(a)).

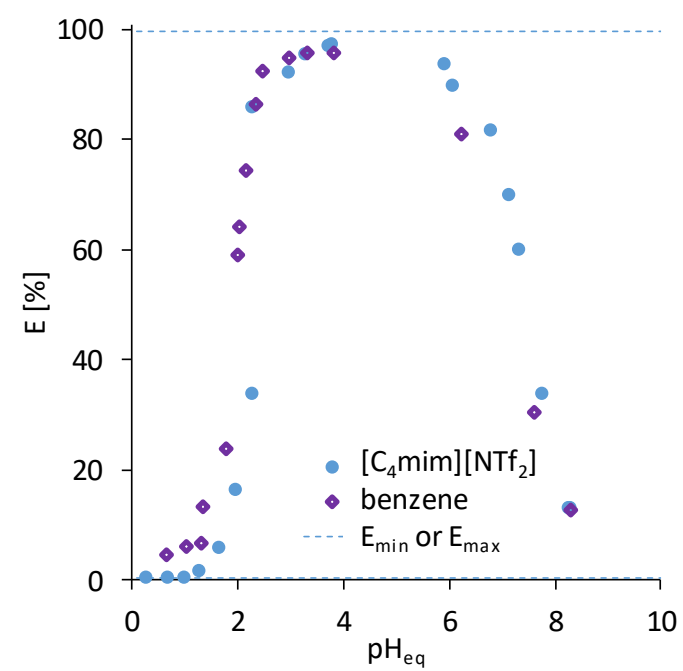

(a)

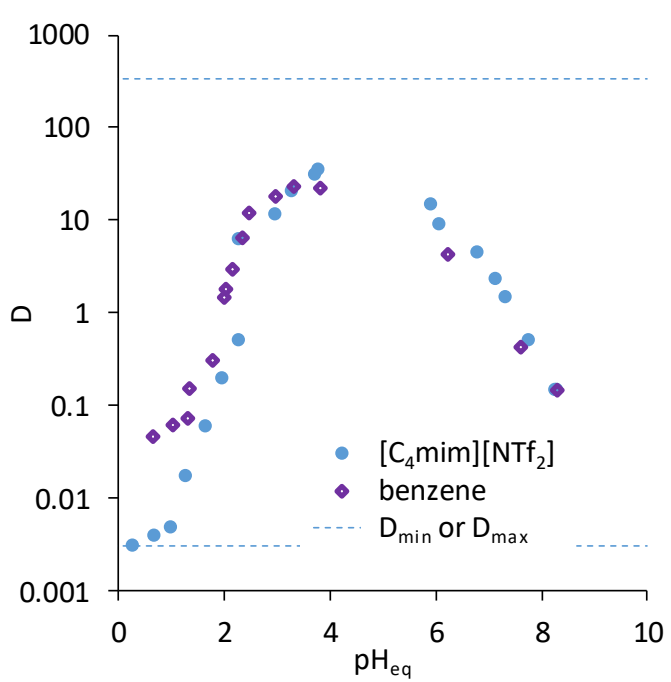

(b)

Figure 3. The dependence of (a) the percentage of extraction (E) and (b) the distribution ratio (D) on the equilibrium $\mathrm{pH}$ value for extraction of ferric ion into $0.1 \mathrm{M}$ TTA in various ionic liquids or in benzene $\left(\mathrm{V}_{\text {org }} / \mathrm{V}_{\text {aq }}=1, \mathrm{~T}=25^{\circ} \mathrm{C}, \mathrm{t}(\mathrm{contact})=30\right.$ $\min )$ 
Distribution ratio dependence on equilibrium $\mathrm{pH}$ showed several linear sections in logarithmic scale in the $\mathrm{pH}$ range $0-4$ indicating change of the extraction mechanism (Figure 3.(b)). The outer sections are quite short to characterize, however the middle section allowed to calculate slopes and appropriate $\mathrm{pH}_{1 / 2}$ values, all summarized in Table 2 . It can be seen that the slope achieved for [ $\left.\mathrm{C}_{4} \mathrm{mim}\right]\left[\mathrm{NTf}_{2}\right]$ is steeper to that achieved for benzene as solvent, but in the tested concentration range TTA in $\left[\mathrm{C}_{4} \mathrm{mim}\right]\left[\mathrm{NTf}_{2}\right]$ provides lower distribution ratios. However, the curve line describing the extraction of Fe(III) into IL and appropriate $\mathrm{pH}_{1 / 2}$ value are shifted to higher $\mathrm{pH}$ values comparing to the extraction into organic phase with benzene.

Table 2. Slopes and $\mathrm{pH}_{1 / 2}$ values calculated from the dependence of $\mathrm{D}$ on equilibrium $\mathrm{pH}$ for extraction of ferric ion into $0.1 \mathrm{M}$ TTA in $\left[\mathrm{C}_{4} \mathrm{mim}\right]\left[\mathrm{NTf}_{2}\right]$ or in benzene $\left(\mathrm{V}_{\text {org }} / \mathrm{V}_{\mathrm{aq}}=1, \mathrm{~T}=25^{\circ} \mathrm{C}, \mathrm{t}(\right.$ contact $\left.)=30 \mathrm{~min}\right)$.

\begin{tabular}{|c|c|c|}
\hline & {$\left[\mathrm{C}_{4} \mathrm{mim}\right]\left[\mathrm{NTf}_{2}\right]$} & benzene \\
\hline slope & $1.79 \pm 0.24$ & $1.82 \pm 0.12$ \\
\hline $\mathrm{pH}_{1 / 2}$ & $2.78 \pm 0.41$ & $1.91 \pm 0.19$ \\
\hline
\end{tabular}

In addition, the dependences of distribution ratio on concentration of TTA were tested at $\mathrm{pH}=2.3$ for both solvents (Figure 4.). The small difference between the slopes can be seen indicating again different behavior of the chelate in the case of ionic liquid solvent.

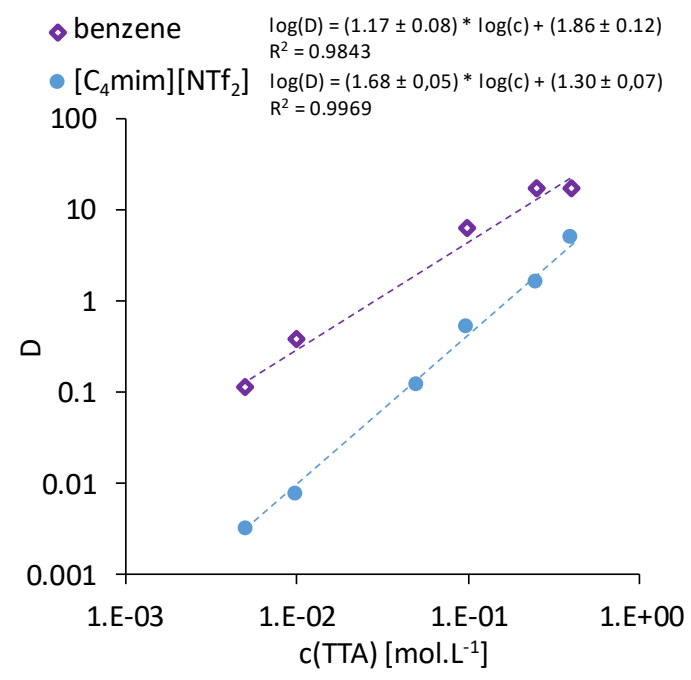

Figure 4. The dependence of the distribution ratio (D) on the concentration of TTA at constant equilibrium pH value for extraction of ferric ion into TTA in $\left[\mathrm{C}_{4} \mathrm{mim}\right]\left[\mathrm{NTf}_{2}\right]$ or in benzene $\left(\mathrm{V}_{\text {org }} / \mathrm{V}_{\mathrm{aq}}=1, \mathrm{~T}=25^{\circ} \mathrm{C}, \mathrm{t}(\mathrm{contact})=30 \mathrm{~min}\right)$

\section{8-hydroxyquinoline}

The effect of different ionic liquids on the extraction of Fe(III) using amphoteric chelating agent 8-hydroxychinoline (8HQ) as extracting agent was studied. It is an amphoteric chelating agent with hydration constant $\mathrm{pK}_{\mathrm{H}}=5.0$ and dissociation constant $\mathrm{pKa}=9.66$ [11]. As the reference organic solvent, chloroform was used in this case because it is commonly used as the most suitable VOC solvent for 8-hydroxyquinoline [6]. As in the both cases above, the trend of the dependences on the equilibrium $\mathrm{pH}$ is similar for all tested solvents (Figure 5.(a)) - imidazolium ionic liquids, ammonium ionic liquids and chloroform. At $\mathrm{pH} \sim 1$, the extraction of iron rises sharply and the maximal extraction $(>99.7 \%)$ is achieved at $\mathrm{pH} \sim 3$ for all solvents. Using ionic liquids, the extraction did not decrease significantly in the studied $\mathrm{pH}$ range (up to 9). In chloroform, the slight reduction of extraction at $\mathrm{pH}>6$ was observed. 


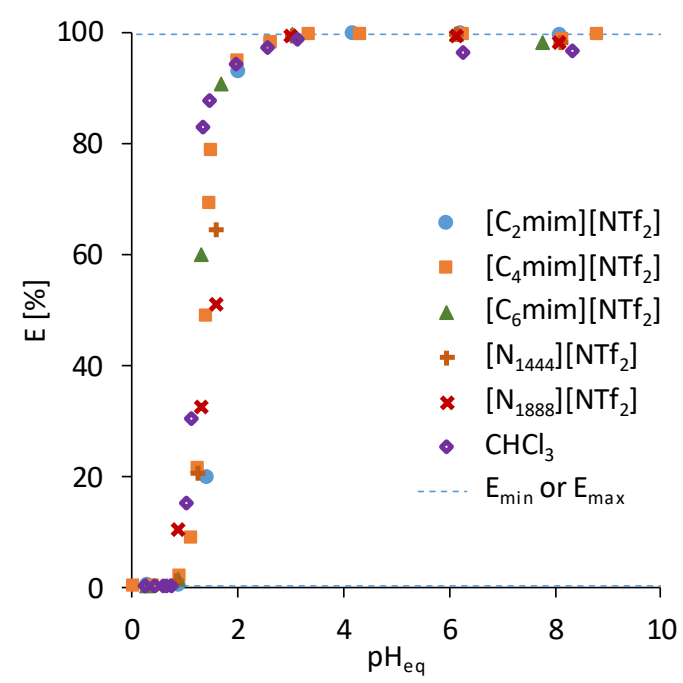

(a)

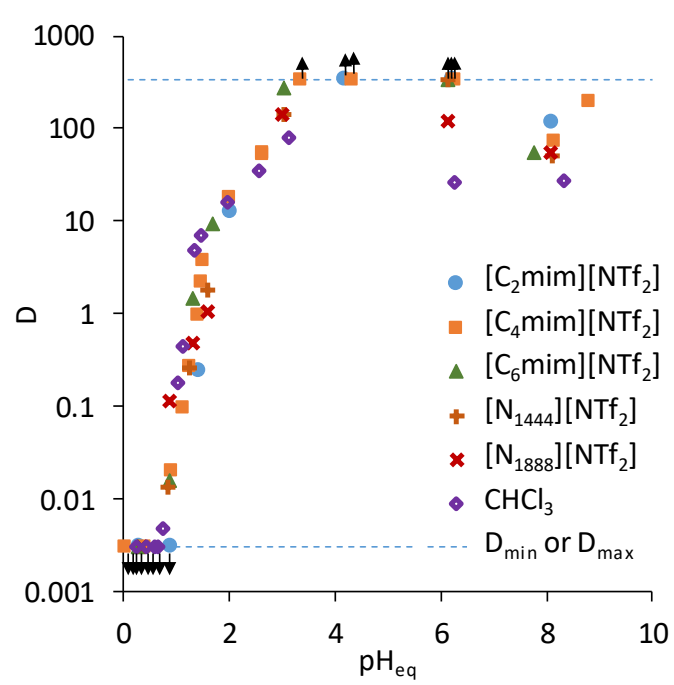

(b)

Figure 5. The dependence of (a) the percentage of extraction (E) and (b) the distribution ratio (D) on the equilibrium $\mathrm{pH}$ value for extraction of ferric ion into $0.1 \mathrm{M} 8 \mathrm{HQ}$ in various ionic liquids or in chloroform $\left(\mathrm{V}_{\text {org }} / \mathrm{V}_{\mathrm{aq}}=1, \mathrm{~T}=25^{\circ} \mathrm{C}, \mathrm{t}(\mathrm{contact})=\right.$ $30 \mathrm{~min})$

The semi-logarithmic dependence of distribution ratio on the equilibrium $\mathrm{pH}$ value shows two easily definable sections with different slopes (Figure 5.(b)), which suggests that the reaction mechanism is most likely to change. The parameters characterizing the $\log \mathrm{D}$ dependence on $\mathrm{pH}$ value are summarized in Table 3 . The effect of alkyl chain length cannot be clearly quantified as well as the trend in $\mathrm{pH}_{1 / 2}$ values, in all the cases the differences do not exceed the uncertainty intervals. However, for all ionic liquids systems and at the given $8-\mathrm{HQ}$ concentration, the $\mathrm{pH}_{1 / 2}$ values are higher than in the reference $\mathrm{CHCl}_{3}$ system.

Table 3. Slopes and $\mathrm{pH}_{1 / 2}$ values calculated from the dependence of $\mathrm{D}$ on equilibrium $\mathrm{pH}$ for extraction of ferric ion into $0.1 \mathrm{M} 8 \mathrm{HQ}$ in various ionic liquids or in chloroform

$\left(\mathrm{V}_{\text {org }} / \mathrm{V}_{\text {aq }}=1, \mathrm{~T}=25^{\circ} \mathrm{C}, \mathrm{t}(\right.$ contact $\left.)=30 \mathrm{~min}\right)$. Bracketed values are approximations due to limited number of experimental values.

\begin{tabular}{|c|c|c|c|c|c|c|}
\hline & {$\left[\mathrm{C}_{2} \mathrm{mim}\right]\left[\mathrm{NTf}_{2}\right.$} & {$\left[\mathrm{C}_{4} \mathrm{mim}\right]\left[\mathrm{NTf}_{2}\right]$} & {$\left[\mathrm{C}_{6} \mathrm{mim}\left[\mathrm{NTf}_{2}\right]\right.$} & {$\left[\mathrm{N}_{1444}\right]\left[\mathrm{NTf}_{2}\right]$} & {$\left[\mathrm{N}_{1888}\right]\left[\mathrm{NTf}_{2}\right]$} & $\mathrm{CHCl}_{3}$ \\
\hline $\begin{array}{c}\text { slope } \\
\mathrm{pH} \sim 1.2\end{array}$ & $3.19 \pm 0.26$ & $3.82 \pm 0.15$ & $3.38 \pm 0.60$ & $2.80 \pm 0.19$ & $(2,97)$ & $4.96 \pm 0.12$ \\
\hline $\begin{array}{l}\text { slope } \\
\mathrm{pH} \sim 2\end{array}$ & $(0.66)$ & $1.00 \pm 0.06$ & $1.24 \pm 0.19$ & $1.48 \pm 0.18$ & $1.44 \pm 0.03$ & $0.66 \pm 0.03$ \\
\hline $\mathrm{pH}_{1 / 2}$ & $1.66 \pm 0.19$ & $1.37 \pm 0.08$ & $1.35 \pm 0.34$ & $1.49 \pm 0.13$ & $1.53 \pm 0.05$ & $1.19 \pm 0.04$ \\
\hline
\end{tabular}

The distribution ratio dependences on various $8 \mathrm{HQ}$ concentrations in [ $\left.\mathrm{C}_{4} \mathrm{mim}\right]\left[\mathrm{NTf}_{2}\right.$ ] in logarithmic scales at two different equilibrium $\mathrm{pH}$ values were measured (Figure 6). From these data, the slopes of these dependences were calculated. At lower $\mathrm{pH}$ the slope is between 1.5 and $2(1.78 \pm 0.12)$, but at higher $\mathrm{pH}$ value, it is close to one $(0.95 \pm 0.03)$. This indicates change in the number of $8-\mathrm{HQ}$ in the extracted species above $\mathrm{pH} \sim 2$. 


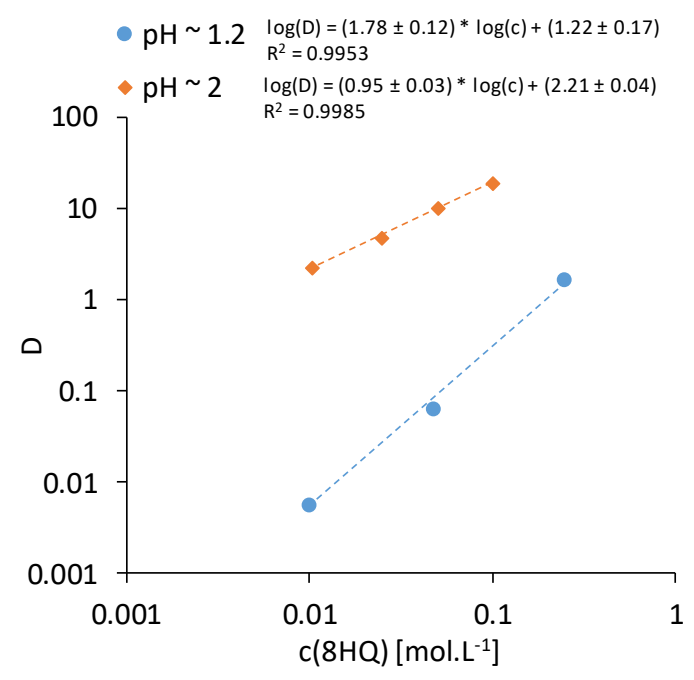

Figure 6. The dependence of the distribution ratio (D) on the concentration of $8 \mathrm{HQ}$ at constant equilibrium $\mathrm{pH}$ value for extraction of ferric ion into $8 \mathrm{HQ}$ in $\left[\mathrm{C}_{4} \mathrm{mim}\right]\left[\mathrm{NTf}_{2}\right]$

$\left(\mathrm{V}_{\text {org }} / \mathrm{V}_{\mathrm{aq}}=1, \mathrm{~T}=25^{\circ} \mathrm{C}, \mathrm{t}(\right.$ contact $\left.)=30 \mathrm{~min}\right)$

\section{Extraction from aqueous solution containing common complexing agents}

As the representatives of the substances widely known as complicating the iron extraction, namely in trace concentrations, citric acid and oxalic acid were selected. All experiments were performed with solution of single acids or their mixture at the natural initial $\mathrm{pH}$ of the solutions $(\mathrm{pH}=2.1-3)$. Based on the results above, $\left[\mathrm{C}_{4} \mathrm{mim}\right]\left[\mathrm{NTf}_{2}\right]$ was used as a representative of ionic liquids and for comparison, the respective classical solvents were used.

All experimental results are summarized in Table 4. It can be seen that the effect of citric acid suppressing iron extraction is much smaller than that of oxalic acid in all tested systems. And - as supposed - with increasing concentration of complexing acid less iron is extracted. Any synergy or antergy was not observed between the complexing acids in the range of E uncertainties.

AcAc was showed to be strong enough to extract Fe(III) from the solution of citric acid. Comparing to the extraction using benzene as the solvent, the extraction was up to $10 \%$ lower with respect to the concentration of citric acid. In the case of oxalic acid and the mixture, the extraction did not exceed $6 \%$. In this system, the use of ionic liquids and combination with AcAc is not bringing any advantage comparing to the AcAc solution in benzene; and AcAc is in both case not strong enough to pass complexing abilities of citric and namely oxalic acid.

Although iron is extracted relatively efficiently from $\mathrm{HNO} 3$ with TTA, its extraction ability when using oxalic and/or citric acid solutions is relatively small. Even increase of TTA concentration did not result in effective Fe(III) extraction.

The extraction with $8 \mathrm{HQ}$ was much more efficient than with acetylacetone and TTA. At extractant concentration of 0.5 mol.L-1, complete extraction was achieved from all solutions, including oxalic acid solutions and a mixture of both complexing acids. Additionally, it can be clearly seen that the extraction into ionic liquid is much more efficient than into $\mathrm{CH}_{3} \mathrm{Cl}$. 
Table 4. The effect of citric and oxalic acids on the extraction of ferric ion into various organic phase $\left(\mathrm{V}_{\text {org }} / \mathrm{V}_{\mathrm{aq}}=1, \mathrm{~T}=25^{\circ} \mathrm{C}, \mathrm{t}(\right.$ contact $\left.)=30 \mathrm{~min}\right)$.

\begin{tabular}{|c|c|c|c|c|c|c|}
\hline & \multirow{2}{*}{$\begin{array}{l}\text { No com- } \\
\text { plexant }\end{array}$} & \multicolumn{2}{|c|}{$\mathbf{H}_{3} \mathrm{Cit}$} & \multicolumn{2}{|c|}{$\mathrm{H}_{2} \mathrm{Ox}$} & \multirow{2}{*}{$\begin{array}{l}0.005 \mathrm{M} \mathrm{H}_{3} \mathrm{Cit} \\
+0.01 \mathrm{M} \mathrm{H}_{2} \mathrm{Ox}\end{array}$} \\
\hline & & $0.005 \mathrm{M}$ & $0.01 \mathrm{M}$ & $0.005 \mathrm{M}$ & $0.01 \mathrm{M}$ & \\
\hline $\begin{array}{l}0.5 \mathrm{M} \text { AcAc } \\
\text { in benzene }\end{array}$ & $97.5 \pm 0.5 \%$ & $98.9 \pm 0.4 \%$ & $95.2 \pm 0.4 \%$ & $2.3 \pm 0.1 \%$ & $5.2 \pm 0.1 \%$ & $5.1 \pm 0.1 \%$ \\
\hline $\mathrm{pH}_{\mathrm{eq}}$ & 2.3 & 2.8 & 2.6 & 2.4 & 2.1 & 2.1 \\
\hline $\begin{array}{c}0.5 \mathrm{M} \mathrm{AcAc} \\
\text { in }\left[\mathrm{C}_{4} \mathrm{mim}^{2}\right]\left[\mathrm{NTf}_{2}\right]\end{array}$ & $94.7 \pm 0.5 \%$ & $91.5 \pm 0.4 \%$ & $85.8 \pm 0.4 \%$ & $0.4 \pm 0.1 \%$ & $0.1 \pm 0.1 \%$ & $0.1 \pm 0.1 \%$ \\
\hline $\mathrm{pH}_{\mathrm{eq}}$ & 2.7 & 2.8 & 2.6 & 2.4 & 2.1 & 2.1 \\
\hline $\begin{array}{c}\text { 0.1M TTA } \\
\text { in }\left[\mathrm{C}_{4} \mathrm{mim}^{2}\left[\mathrm{NTf}_{2}\right]\right.\end{array}$ & $33.8 \pm 0.2 \%$ & $3.3 \pm 0.1 \%$ & $0.2 \pm 0.1 \%$ & $4.3 \pm 0.1 \%$ & $0.4 \pm 0.1 \%$ & $0.2 \pm 0.1 \%$ \\
\hline $\mathrm{pH}_{\mathrm{eq}}$ & 2.3 & 2.6 & 2.4 & 2.8 & 2.0 & 2.0 \\
\hline $\begin{array}{c}\text { 0.4M TTA } \\
\text { in }\left[\mathrm{C}_{4} \mathrm{mim}^{-}\right]\left[\mathrm{NTf}_{2}\right]\end{array}$ & $87.0 \pm 1.1 \%$ & $15.1 \pm 0.1 \%$ & $2.9 \pm 0.1 \%$ & $14.9 \pm 0.1 \%$ & $1.1 \pm 0.1 \%$ & $1.5 \pm 0.1 \%$ \\
\hline $\mathrm{pH}_{\mathrm{eq}}$ & 3.3 & 2.6 & 2.4 & 2.8 & 2.1 & 2.1 \\
\hline $\begin{array}{c}0.1 \mathrm{M} 8 \mathrm{HQ} \\
\text { in } \mathrm{CHCl}_{3}\end{array}$ & $>99.7 \%$ & $>99.7 \%$ & > $99.7 \%$ & $22.3 \pm 1.3 \%$ & $6.7 \pm 1.2 \%$ & $5.9 \pm 0.1 \%$ \\
\hline $\mathrm{pH}$ eq & 3.1 & 3.8 & 3.5 & 3.8 & 3.4 & 3.3 \\
\hline $\begin{array}{c}0.1 \mathrm{M} 8 \mathrm{HQ} \\
\text { in }\left[\mathrm{C}_{4} \mathrm{mim}^{2}\left[\mathrm{NTf}_{2}\right]\right.\end{array}$ & $>99.7 \%$ & $>99.7 \%$ & > $99.7 \%$ & $>99.7 \%$ & $87.2 \pm 0.4 \%$ & $74.2 \pm 0.3 \%$ \\
\hline $\mathrm{pH}_{\mathrm{eq}}$ & 4.3 & 5.0 & 4.7 & 5.0 & 4.5 & 4.3 \\
\hline $\begin{array}{c}0.5 \mathrm{M} 8 \mathrm{HQ} \\
\text { in } \mathrm{CHCl3}\end{array}$ & > $99.7 \%$ & $>99.7 \%$ & > $99.7 \%$ & $97.9 \pm 0.5 \%$ & $79.8 \pm 0.4 \%$ & $82.0 \pm 0.4 \%$ \\
\hline $\mathrm{pH}_{\mathrm{eq}}$ & 4.0 & 4.2 & 4.0 & 4.1 & 3.9 & 3.8 \\
\hline $\begin{array}{c}0.5 \mathrm{M} 8 \mathrm{HQ} \\
\text { in }\left[\mathrm{C}_{4} \mathrm{mim}^{2}\right]\left[\mathrm{NTf}_{2}\right]\end{array}$ & $>99.7 \%$ & $>99.7 \%$ & > 99.7 \% & $>99.7 \%$ & $>99.7 \%$ & $>99$. \\
\hline $\mathrm{pH}_{\mathrm{eq}}$ & 4.3 & 5.6 & 5.3 & 5.7 & 5.3 & 5.1 \\
\hline
\end{tabular}

\section{Conclusions}

Our experiments and results covered area of the chelate assisted extraction of iron(III) into ionic liquids. With respect to the aims of the work, most of the measured values are suitable for further investigation and deeper study on water/ionic liquid biphasic systems.

The achieved results clearly show that iron (III) is extracted from nitric acid solutions and from given aqueous complexing environment. From the set of chelating agents and regarding organic phase composition, iron is quantitatively extracted with $0.5 \mathrm{M}$ 8-hydroxyquiniline solution in $\left[\mathrm{C}_{4} \mathrm{mim}\right]\left[\mathrm{NTf}_{2}\right]$ at the natural $\mathrm{pH}$ of the solution. Such result indicates ability of such system to separate iron and concentrate it from diluted systems without any additions of buffers or mineral acids, which can further influence speciation and purity of the resulting separated product.

Acknowledgement:

This work was carried out within by grant project of the Technology Agency of the Czech Republic TH01020381 and within the Center for advanced applied science, project number CZ.02.1.01/0.0/0.0/16_019/0000778, both supported by the Ministry of Education, Youth and Sports of the Czech Republic.

\section{References}

1. Smirnova, S.V.; Samarina, T.O.; Pletnev, I.V. Novel ionic liquids for liquid-liquid extraction. In Analytical Applications od Ionic Liquids; M. Koel (Ed.) World Scientific Publishing Europe Ltd. ISBN 9781786340719, 2017, 139-189

2. Freemantle M. Properties of Ionic Liquids. In An Introduction to Ionic Liquids, The Royal Society of Chemistry, 2010, Cambridge

3. Dietz, M.L. Ionic Liquids as Extraction Solvents: Where do We Stand? Separation Science 2006, 41, 2047-2063.

4. Shoja, S. M. R;, Abdouss, M.; Beigi, A. A. M. Synthesis and characterization of physicochemical 
properties of imidazolium-based ionic liquids and their application for simultaneous determination of sulfur compounds, Journal of Molecular Structure 2021, 1230, 129917.

5. Sun, X.; Luo, H.; Dai, S. Ionic liquids-based extraction: a promising strategy for the advanced nuclear fuel cycle. Chem. Rev. 2012, 112, 4, 2100-2128

6. Cubova, K.; Semelova, M.; Nemec, M.; Straka, M. Separation of Co from simulated decontamination media using ionic liquids, Journal of Radioanalytical and Nuclear Chemistry, 2019,322(2), 1849-1855

7. Parmentier D.; Valia,Y.A.; Metz S.J.; Burheim O.S.; Kroon M.C. Regeneration of ionic liquid tetraoctylammonium oleate after metal extraction. Hydrometallurgy 2015, 158, 56-60.

8. Wellens S; , Goovaerts R.; Moeller C.; Luyten J.; Thijs B.; Binnemans K. Continuous ionic liquid extraction process for the separation of cobalt from nickel. Green Chem. 2013, 11,3160.

9. Counting Statistics and Error Prediction. In Radiation Detection and Measurement, 4nd ed.;Knoll G. F. (ed.); Publisher J. Willey \& Sons, USA, 2010, 94-98

10. Anatassova, M.; Billard, I.; Determination of pKaIL Values of Three Chelating Extractants in ILs: Consequences for the Extraction of $4 \mathrm{f}$ Elements. J Solution Chem 2015, 44, 606-620

11. Kotrly, S.; Sucha, L. Protonation equilibrium constants and Stability constants of complexes with organic ligands. In Chemical equilibria in analytical chemistry (in Czech), SNTL, 1988, 92,133 